\title{
Correction to: Learning About Archaeology and Prehistoric Life
}

\section{The Effects of Two Workshops in Primary Education}

\author{
M. Besse ${ }^{1}$ (D) S. Fragnière ${ }^{1,2} \cdot$ A. Müller $^{2}$ (D) M. Piguet $^{1} \cdot$ L. Dubois $^{3} \cdot$ D. Miéville $^{4}$. \\ S. Schoeb ${ }^{4} \cdot$ D. Schumacher ${ }^{3}$
}

Published online: 10 July 2019

(C) The Author(s) 2019

\section{Correction to: Science \& Education https://doi.org/10.1007/s11191-019-00047-z}

The original version of this article unfortunately contains incorrect figures 6 to 13 .

The online version of the original article can be found at https://doi.org/10.1007/s11191-019-00047-z
A. Müller
andreas.mueller@unige.ch

1 Section of Earth and Environmental Sciences, Department F.-A. Forel for environmental and aquatic sciences, Laboratory of prehistoric archaeology and anthropology, University of Geneva, Geneva, Switzerland

2 Faculty of Sciences, Section of Physics, and University Institute for Teacher Education (IUTE), University of Geneva, Geneva, Switzerland

3 Faculty of Psychology and Educational Science, Laboratoire de Didactique des Sciences, and University Institute for Teacher Education (IUTE), University of Geneva, Geneva, Switzerland

4 Department d'Instruction Publique, Direction de l'enseignement obligatoire-enseignement primaire, Geneva, Switzerland 


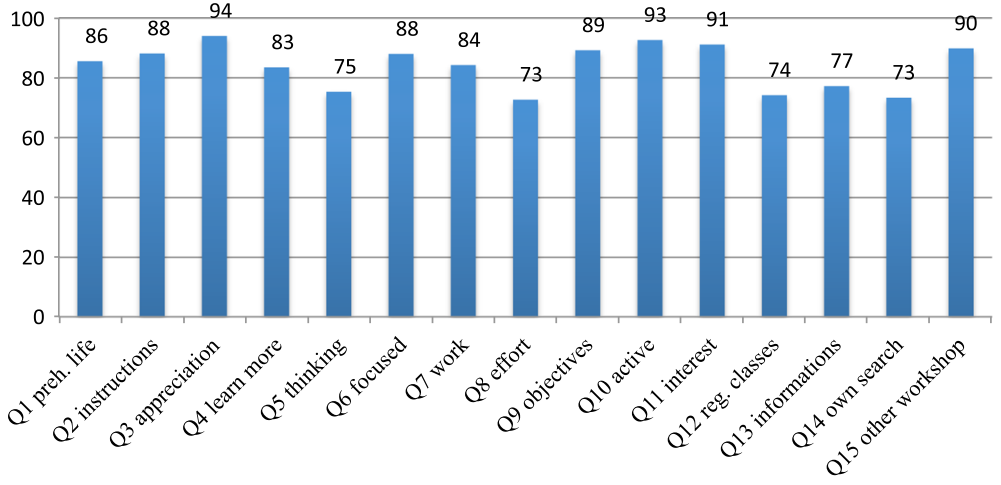

\section{Organisation}

2. J'ai bien compris les consignes de l'atelier (I understood the instructions for the workshop)

9. J'ai bien compris les objectifs de l'atelier (I understood the objectives of the workshop)

13. Avant l'atelier, nous avons reçu des informations suffisantes sur ce qui va se passer (before the

workshop, we received sufficient information on what was going to happen)

Educational value

1. L'atelier m'a permis de mieux comprendre comment vivaient les Hommes préhistoriques (the workshop

allowed me to better understand how prehistoric people lived)

5. L'atelier encourage à penser (the workshop made me think)

7. L'atelier m'a permis de mieux comprendre comment travaillent les archéologues (the workshop helped

me better understand how archaeologists work)

12. L'atelier aide à mieux comprendre les contenus des classes régulières (the workshop helped me understand the contents of regular lessons)

\section{Engagement}

4. L'atelier m'a donné envie d'en savoir plus sur le travail des archéologues (the workshop made me want to learn more about archaeologist's work)

6. J'étais concentré(e) lors de l'atelier (I was focused during the workshop)

8. J'ai investi plus d'effort lors dans l'atelier que dans des cours réguliers (I invested more effort into the workshop than in regular lessons)

10. J'ai participé activement à l'atelier (I actively participated in the workshop)

11. Les activités ont été intéressantes pour moi (the activities were interesting for me)

14. À la maison, j'aimerais chercher dans des livres, sur internet, etc. pour en savoir plus sur les thèmes de

l'atelier (at home, I'd like to look up in books, internet, etc. to know more about the themes of the workshop)

15. Aimerais-tu un autre atelier sur la préhistoire? (would you like another workshop on prehistory?)

General appreciation/enjoyment

3. J'ai bien aimé l'atelier (I liked the workshop)

Fig. 6 Workshop appreciation by students (in \% of maximal value) 
The correct figure 7 is shown below.

a

8. Lifestyle

$>$ Circle the correct/s answer/s.

How do you think men and women lived 20,000 years ago?

They lived at the entrance of the caves

They lived in tents

They lived by hunting, fishing and gathering

They lived in the depths of the caves

They had no home and were constantly moving from place to place

They lived in houses and villages

They lived in hammocks or treehouses perched in the trees

I have no opinion on this subject

\section{b}

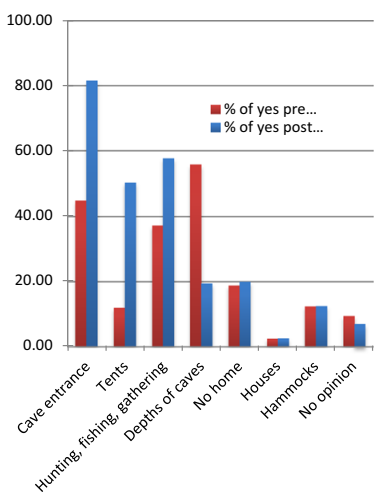

Fig. 7 a Item on lifestyle of prehistoric people. b Results (\% of yes answers; pre-test (left) and post-test (right)

The correct figure 8 is shown below.

a

11. Awl function

(Circle the correct/s answer/s.

According to you, what was the functions of the bone awl?

To pierce animal skins

To decorate objects

Help with sewing

To pierce bark of wood

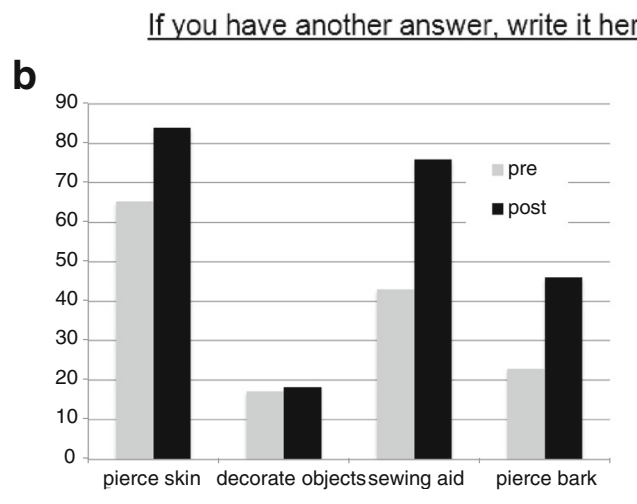

Fig. 8 a Item on bone awl function. b Results (\% of yes answers; pre and post-test) 
The correct figure 9 is shown below.

a

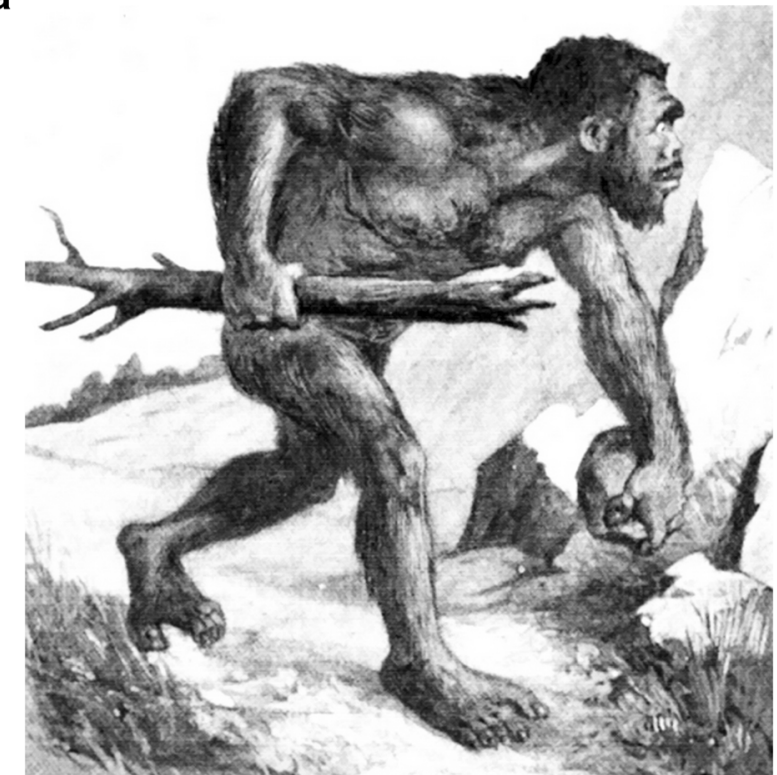

b 1. Prehistoric Man

Circle the adjectives that, according to you, describe Prehistoric Man well in the list below. You can also add other adjectives.

Ugly

\section{Smart}

Dirty

Violent

Sensitive

Stupid

I have no opinion on this subject

Fig. 9 a Typical illustration corresponding to the "brute caveman" stereotype (public domain, Wikimedia 2018) as used in the following item: Does this picture correspond to how you imagine a prehistoric man? b Another item probing for the mental representation of prehistoric Man: Circle the adjectives that, according to you, describe prehistoric Man. You can also add other adjectives 
The correct figure 10 is shown below.

\section{a}

The work of an archaeologist can be compared to:

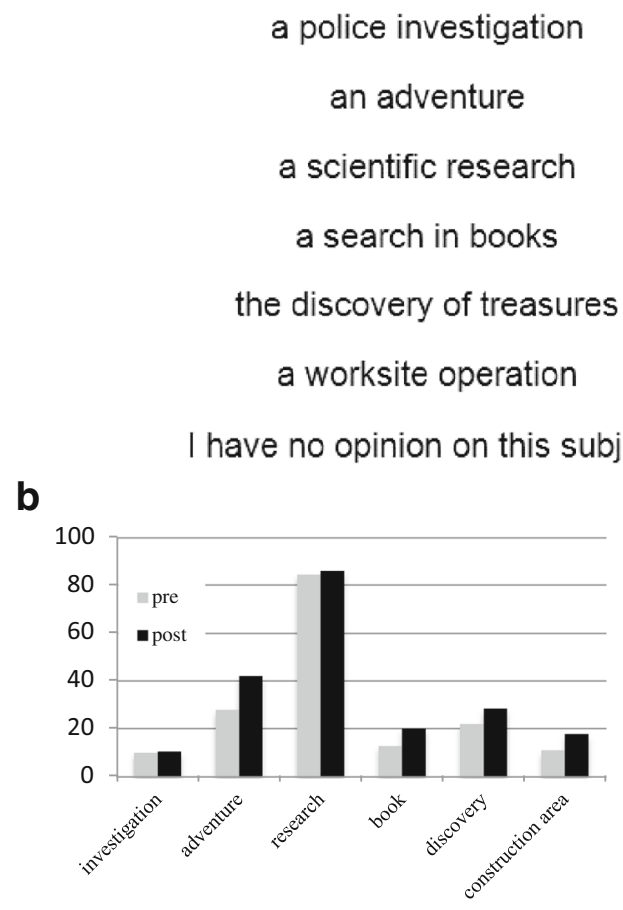

Fig. 10 a Question on archaeology as work. b Results (\% of answers; pre and post-test) 
The correct figure 11 is shown below.

a

1. Climate

$>$ Circle the correct/s answer/s.

According to you what was the climate about $20,000-30,000$ years ago when men were painting in caves?

It was colder

Glaciers covered part of Europe

The sea level was lower

It was warmer

It was hot and humid

The climate was the same as today

I have no opinion on this subject

b

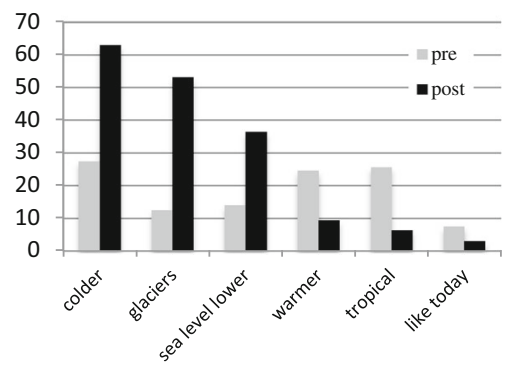

Fig. 11 a Question on climate. b Results (\% of answers; pre- and post-tests) 
The correct figure 12 is shown below.

\section{Animal parts}

Make all the links possible between the two columns below

\section{According to you, which parts of the animal could be used? What function each} of these elements had?

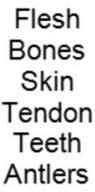

\author{
To feed themselves \\ To make clothes \\ To make tools \\ To make jewellery \\ To make blankets \\ To cover tents \\ To make ropes \\ To make weapons
}

Fig. 12 An item which was not well understood by many students

The correct figure 13 is shown below.

1. It makes the life of these far-away men and women much more closer and concrete

2. Directly linked to the school program

3. Practical aspect and active participation of the students + entertainment aspect

4. It is concrete and illustrative for the kids

5. Excellent idea. The workshops blend history, creative activities and relational aspects. Cantonal examinations have included this subject

6. It was simply awesome. The teachers do not have the time, budget or material to organise that kind of workshops

7. It is not often that practical activities are found in history (and of quality)

Fig. 13 Why a generalisation to other classes would be desirable (reasons given by teachers)

The original article has been corrected.

Open Access This article is distributed under the terms of the Creative Commons Attribution 4.0 International License (http://creativecommons.org/licenses/by/4.0/), which permits unrestricted use, distribution, and reproduction in any medium, provided you give appropriate credit to the original author(s) and the source, provide a link to the Creative Commons license, and indicate if changes were made.

Publisher's Note Springer Nature remains neutral with regard to jurisdictional claims in published maps and institutional affiliations. 